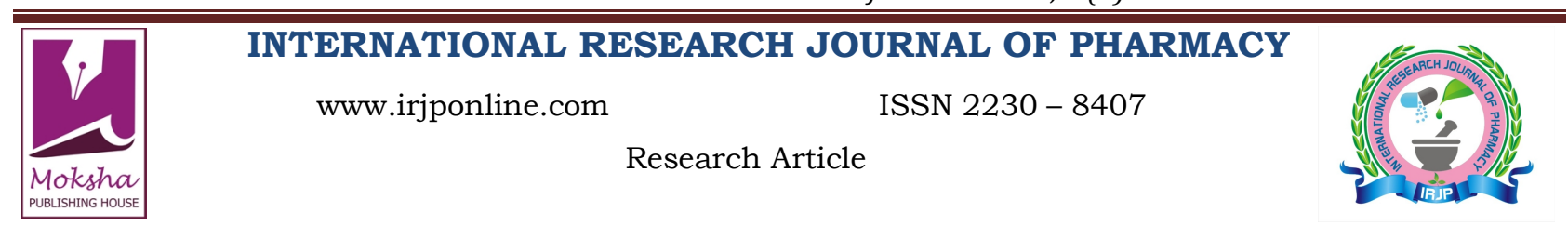

\title{
DEVELOPMENT AND VALIDATION OF RP-HPLC METHOD FOR THE ESTIMATION OF PRASUGREL IN BULK AS WELL IN PHARMACEUTICAL DOSAGES FORM
}

S. Ashutosh Kumar*1, J.V.L.N.Seshagiri Rao ${ }^{2}$, K. Jhansi Rani ${ }^{1}$, S. S. S. Jaya Madhuri ${ }^{1}$, T. S. R. K. V. Prasad ${ }^{1}$

${ }^{1}$ A.K.R.G College of Pharmacy, Nallajerla, West Godavari, A.P. India

${ }^{2}$ Pharmaceutical Analysis, Yalamarty College of Pharmacy, Tarluwada Visakhapatnam, A.P, India

Email: ashu_mpharm2007@rediffmail.com

Article Received on: 20/01/13 Revised on: 21/02/13 Approved for publication: 11/03/13

DOI: $10.7897 / 2230-8407.04355$

IRJP is an official publication of Moksha Publishing House. Website: www.mokshaph.com

(C) All rights reserved.

\section{ABSTRACT}

This study was designed to develop and validate a simple, sensitive, precise, and specific reverse phase high-performance liquid chromatographic (HPLC) method for the determination of Prasugrel in bulk and its tablet dosage forms. The HPLC separation was carried out by reverse phase chromatography on XTerra column $\mathrm{C} 18(4.6 \mathrm{x} 150 \mathrm{~mm}, 5 \mu \mathrm{m})$ with a mobile phase composed Potassium Dihydrogen phosphate and the pH has been adjusted to 3.0 by Orthophosporic Acid \& Acetonitrile in the ration of 40:60 v/v in isocratic mode at a flow rate of $1.0 \mathrm{ml} / \mathrm{min}$. The run time has been maintained 5mins. The detection was monitored at $210 \mathrm{~nm}$. The Accuracy was calculated and the \% Recovery was found $99.0 \%-101.8 \%$ and reproducibility was found to be satisfactory. The calibration curve for Prasugrel was linear from 20 to60 $\mu \mathrm{g} / \mathrm{ml}$. The inter-day and intra-day precision was found to be within limits. The proposed method has adequate sensitivity, reproducibility, and specificity for the determination of Prasugrel in bulk and its tablet dosage forms. The limit of detection and limit of quantification for Prasugrel were found to be $0.07 \mu \mathrm{g} / \mathrm{ml}$ and $0.2 \mu \mathrm{g} / \mathrm{ml}$ respectively. The present work was undertaken with the aim to develop and validate a rapid and consistent RP- HPLC in which the peaks will be appear with a short period of time as per ICH guideline. The proposed method is simple, fast, accurate, and precise for the quantification of Prasugrel in the dosage form, bulk drugs as well as for routine analysis in quality control. Key Words: High Performance Liquid Chromatography; Potassium Dihydrogen Phosphate; Acetonitrile; Prasugrel; Accuracy; Quantification.

\section{INTRODUCTION}

Prasugrel (Fig. 1) is chemically $(R S)-5$-[2-cyclopropyl-1-(2fluorophenyl)-2-oxoethyl]-4, 5, 6, 7-tetrahydrothieno [3, 2-c] pyridin-2-yl acetate. Prasugrel is a novel third-generation oral thienopyridine that reduces the tendency of platelets, the blood particles responsible for clotting, from sticking or clumping together ${ }^{1}$. Prasugrel blocks a specific receptor on the platelet surface, P2Y12 adenosine diphosphate (ADP), preventing platelets from clumping, which can result in clogged arteries and may lead to a heart attack ${ }^{2}$. Prasugrel is more effective by preventing ischemic events in patients with acute coronary syndrome undergoing percutaneous coronary intervention, increase in bleeding and improved net clinical outcome ${ }^{3}$. Clopidogrel, unlike Prasugrel, was issued a black box warning from the FDA on March 12, 2010, as the estimated $2-14 \%$ of the US population that have low levels of the CYP2C19 liver enzyme needed to activate clopidogrel may not get the full effect ${ }^{4}$. Compared to clopidogrel, Prasugrel inhibits adenosine diphosphate-induced platelet aggregation more rapidly, more consistently and to a greater extent than do standard and higher doses of clopidogrel in healthy volunteers and in patients with coronary artery disease $^{5}$. Tests are available to predict if a patient would be susceptible to this problem or $\operatorname{not}^{6-8}$. Unlike clopidogrel, Prasugrel is effective in most individuals, although there have been several case reports of decreased responsiveness to prasugrel $^{9}$. Prasugrel is a member of the thienopyridine class of ADP receptor inhibitors, like Ticlopidine (trade name Ticlid) and Clopidogrel (trade name Plavix). These agents reduce the aggregation ("clumping") of platelets by irreversibly binding to $\mathrm{P} 2 \mathrm{Y}_{12}$ receptors ${ }^{10-14}$.

\section{MATERIAL AND METHOD}

Chemical and Reagent Used: The following chemicals have been procured for the process Water HPLC Grade, Prasugrel Working Standards, Acetonitrile HPLC Grade, Ortho phosphoric acid all the chemicals are procured from Standard
Solutions and Tablets $5 \mathrm{mg}$ have been collected from the Local market and the manufacturer is Glenmark and the Brand name of the Tablet is APLET.

\section{Apparatus and Chromatographic Conditions}

Equipment: High performance liquid chromatography equipped with Auto Sampler and DAD or UV detector.

Column : XTerra column C18 (4.6 x 150mm, $5 \mu \mathrm{m})$

Flow rate: $1.0 \mathrm{~mL}$ per $\mathrm{min}$

Wavelength: $210 \mathrm{~nm}$

Injection volume : $20 \mu \mathrm{l}$

Temperature : Ambient

Run time: $5.0 \mathrm{~min}$

Preparation of Phosphate buffer: Weighed 2.72 grams of potassium Dihydrogen phosphate into a $1000 \mathrm{ml}$ beaker, dissolved and diluted to $1000 \mathrm{ml}$ with HPLC water. Then the $\mathrm{pH}$ was adjusted to 3.0 with Orthophosphoric acid.

Preparation of mobile phase: Mixed a mixture of above buffer $400 \mathrm{~mL}(40 \%)$ and $600 \mathrm{~mL}$ of Acetonitrile HPLC $(60 \%)$ and degas in ultrasonic water bath for 5 minutes. Then it was filtered through $0.45 \mu$ filter under vacuum filtration.

Diluent Preparation: Mobile phase as diluent

\section{Preparation of the Prasugral Standard \& Sample Solution}

Standard Solution Preparation: The Standard Stock Solution has been prepared by weighing accurately and transferred $10 \mathrm{mg}$ of Prasugrel Working standard into a $10 \mathrm{~mL}$ volumetric flask. Added about $7 \mathrm{~mL}$ of Diluent and sonicated to dissolved it completely and make volume up to the mark with the same solvent. Further from the above Stock Solution pipette out $0.4 \mathrm{ml}$ into a $10 \mathrm{ml}$ volumetric flask and diluted up to the mark with diluent. Mixed well and then filtered through $0.45 \mu \mathrm{m}$ filter. 
Sample Solution Preparation: The Sample Stock Solution has been prepared by weighing 5 Prasugral Tablets and calculated the average weight. Then the powders accurately weighed and transferred the sample equivalent to $10 \mathrm{mg}$ of Prasugral into a $10 \mathrm{~mL}$ volumetric flask. Added about $7 \mathrm{~mL}$ of diluent and sonicated to dissolve it completely and make volume up to the mark with diluent. Mixed well and then it was filtered through $0.45 \mu \mathrm{m}$ filter. Further from the Sample Stock Solution pipette out $0.4 \mathrm{ml}$ into a $10 \mathrm{ml}$ volumetric flask and diluted up to the mark with diluent. Mixed well and then it was filtered through $0.45 \mu \mathrm{m}$ filter.

Procedure for Injecting the Sample \& Standard Solutions: Injected $20 \mu \mathrm{L}$ of the standard, sample into the chromatographic system and measured the area for the Prasugral peak and calculated the \%Assay by using suitable formulae.

System Suitability: The Tailing factor for the peak due to Prasugral in Standard solution should not be more than 2.0. The theoretical plates for the Prasugral peak in Standard solution should not less than 2000 .

\section{Calculation for Assay:}

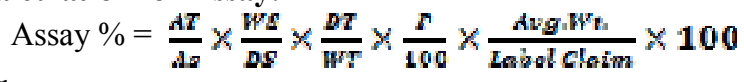

Where:

AT $=$ Peak Area of Prasugral obtained with test preparation AS $=$ Peak Area of Prasugral obtained with standard preparation

WS $=$ Weight of working standard taken in $\mathrm{mg}$ $\mathrm{WT}=$ Weight of sample taken in $\mathrm{mg}$ DS $=$ Dilution of Standard solution $\mathrm{DT}=$ Dilution of sample solution

$\mathrm{P}=$ Percentage purity of working standard

\section{Assay Results}

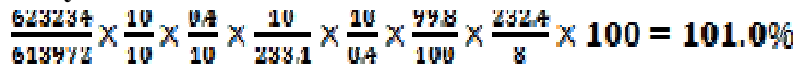

Validation Development

Precision: Precision has been done as follows:

Preparation of stock solution: The Stock Solution has been prepared by weighing accurately and transferred $10 \mathrm{mg}$ of Prasugral Working standard into a $10 \mathrm{~mL}$ volumetric flask added about $7 \mathrm{~mL}$ of Diluent and sonicated to dissolve it completely and make volume up to the mark with the same solvent.

Preparation of $40 \mu \mathrm{g} / \mathrm{ml}$ solution: Further from the above Stock Solution pipette out $0.4 \mathrm{ml}$ into a $10 \mathrm{ml}$ volumetric flask and dilute up to the mark with diluent. Mixed well and then it was filtered through $0.45 \mu \mathrm{m}$ filter.

Procedure for Injecting the Standard Solution: The standard solution was injected for five times and measured the area for all five injections in HPLC. The \%RSD for the area of five replicate injections was found to be within the specified limits. The data are represented in Table 1

Intermediate Precision: To evaluate the intermediate precision (also known as Ruggedness) of the method, Precision was performed on different day by using different make column of same dimensions.
Preparation of stock solution: The Stock Solution has been prepared by weighing accurately and transferred $10 \mathrm{mg}$ of Prasugral Working standard into a $10 \mathrm{~mL}$ volumetric flask added about $7 \mathrm{~mL}$ of Diluent and sonicated to dissolve it completely and make volume up to the mark with the same solvent.

Preparation of $\mathbf{4 0} \boldsymbol{\mu g} / \mathrm{ml}$ solution: Further from the above Stock Solution pipette out $0.4 \mathrm{ml}$ of into a $10 \mathrm{ml}$ volumetric flask and diluted up to the mark with diluent. Mixed well and filtered through $0.45 \mu \mathrm{m}$ filter.

Procedure for Injecting the Standard Solutions: The standard solution was injected for five times and measured the area for all five injections in HPLC. The \%RSD for the area of five replicate injections was found to be within the specified limits. The Data are represented in Table 2.

Accuracy: The accuracy of an analytical procedure has been done as follows:

Preparation of stock Solution: The Stock Solution has been prepared by weighing accurately and transferred $10 \mathrm{mg}$ of Prasugral Working standard into a $10 \mathrm{~mL}$ volumetric flask added about $7 \mathrm{~mL}$ of Diluent and sonicated to dissolve it completely and make volume up to the mark with the same solvent.

Preparation of $40 \mu \mathrm{g} / \mathrm{ml}$ solution: Further from the above Stock Solution pipette out $0.4 \mathrm{ml}$ into a $10 \mathrm{ml}$ volumetric flask and diluted up to the mark with diluent. Mixed well and then it was filter through $0.45 \mu \mathrm{m}$ filter.

Preparation Sample solutions: The Sample Solution has been prepared as follows:

For preparation of $50 \%$ solution (With respect to target Assay concentration)

The Stock Solution has been prepared by weighing accurately and transferred $5.0 \mathrm{mg}$ of Prasugral API sample into a $10 \mathrm{~mL}$ volumetric flask added about $7.0 \mathrm{~mL}$ of Diluent and sonicated to dissolve it completely and make volume up to the mark with the same solvent. Further the above Stock Solution pipette out $0.4 \mathrm{ml}$ into a $10 \mathrm{ml}$ volumetric flask and diluted up to the mark with diluent. Mixed well and then it was filtered through $0.45 \mu \mathrm{m}$ filter.

For preparation of $100 \%$ solution (With respect to target Assay concentration):

The Stock Solution has been prepared by weighing accurately and transferred $10.0 \mathrm{mg}$ of Prasugral API sample into a $10 \mathrm{~mL}$ volumetric flask add about $7 \mathrm{~mL}$ of Diluent and sonicated to dissolved it completely and make volume up to the mark with the same solvent. Further from the above Stock Solution pipette out $0.4 \mathrm{ml}$ into a $10 \mathrm{ml}$ volumetric flask and diluted up to the mark with diluent. Mixed well and then it was filter through $0.45 \mu \mathrm{m}$ filter.

For preparation of $150 \%$ solution (With respect to target Assay concentration):

The Stock Solution has been prepared by accurately weighing and transferred $15.0 \mathrm{mg}$ of Prasugral API sample into a $10 \mathrm{~mL}$ volumetric flask added about $7 \mathrm{~mL}$ of Diluent and sonicated to dissolved it completely and make volume up to the mark with the same solvent. Further from the above Stock Solution 
pipette out $0.4 \mathrm{ml}$ into a $10 \mathrm{ml}$ volumetric flask and diluted up to the mark with diluent. Mixed well and then it was filter through $0.45 \mu \mathrm{m}$ filter.

Procedure for Injecting the Solutions: Injected the standard solution, Accuracy $-50 \%$, Accuracy $-100 \%$ and Accuracy $-150 \%$ solutions. Calculated the Amount found and Amount added for the drug estimation and calculated for the individual recovery and mean recovery values. The data are represented in Table no. 3 .

Linearity: The linearity of the analytical procedure has been done as follows:

Preparation of stock solution: The Stock Solution has been prepared by weighing accurately and transferred $10 \mathrm{mg}$ of Prasugral API sample into a $10 \mathrm{~mL}$ volumetric flask added about $7 \mathrm{~mL}$ of Diluent and sonicated to dissolved it completely and make volume up to the mark with the same solvent. The preparation has been done as follows:

Preparation of Level - I (20 $\mu \mathrm{g} / \mathrm{ml}): 0.2 \mathrm{ml}$ of stock solution has taken in $10 \mathrm{ml}$ of volumetric flask dilute up to the mark with diluent

Preparation of Level - I (30 $\mu \mathrm{g} / \mathrm{ml}): 0.3 \mathrm{ml}$ of stock solution has taken in $10 \mathrm{ml}$ of volumetric flask dilute up to the mark with diluent.

Preparation of Level - II (40 $\mu \mathrm{g} / \mathrm{ml}): 0.4 \mathrm{ml}$ of stock solution taken in $10 \mathrm{ml}$ of volumetric flask dilute up to the mark with diluent.

Preparation of Level - III $(50 \mu \mathrm{g} / \mathrm{ml}): 0.5 \mathrm{ml}$ of stock solution taken in $10 \mathrm{ml}$ of volumetric flask dilute up to the mark with diluent.

Preparation of Level - IV $(60 \mu \mathrm{g} / \mathrm{ml}): 0.6 \mathrm{ml}$ of stock solution taken in $10 \mathrm{ml}$ of volumetric flask dilute up to the mark with diluent.

Procedure for Injecting the Solutions: Injected each level into the chromatographic system and measured the peak area. Plotted the graph of peak area versus concentration (on Xaxis concentration and on $\mathrm{Y}$-axis Peak area) and calculated the correlation coefficient. The data are represented in Table 4.

Limit of Detection: The detection limit of an individual analytical procedure is the lowest amount of analyte in a sample which can be detected but not necessarily quantities as an exact value.

Preparation of $40 \mu \mathrm{g} / \mathrm{ml}$ solution: The Stock Solution has been prepared by weighing accurately and transferred $10 \mathrm{mg}$ of Prasugral Working standard into a10 $\mathrm{ml}$ volumetric flask added about $7 \mathrm{~mL}$ of Diluent and sonicated to dissolved it completely and make volume up to the mark with the same solvent. Further from the above Stock Solution pipette out $0.4 \mathrm{ml}$ into a $10 \mathrm{ml}$ volumetric flask and diluted up to the mark with diluent. Mixed well and then it was filtered through $0.45 \mu \mathrm{m}$ filter.

Preparation of $1.8 \%$ solutions At Specification level (0.07 $\mu \mathrm{g} / \mathrm{ml}$ solution): Pipette out $1 \mathrm{~mL}$ of $10 \mu \mathrm{g} / \mathrm{ml}$ solution into a $10 \mathrm{ml}$ of volumetric flask and diluted up to the mark with diluent. Pipette $1 \mathrm{~mL}$ of $10 \mu \mathrm{g} / \mathrm{ml}$ solution into a $10 \mathrm{ml}$ of volumetric flask and diluted up to the mark with diluent. Further pipette $1.8 \mathrm{~mL}$ of above diluted solution into a $10 \mathrm{ml}$ of volumetric flask and dilute up to the mark with diluent.

\section{Calculation of S/N Ratio:}

Average Baseline Noise obtained from Blank: $49 \mu \mathrm{V}$

Signal Obtained from LOD solution $(1.5 \%$ of target assay concentration): $148 \mu \mathrm{V}$

$\mathrm{S} / \mathrm{N}=148 / 49=3.01$

Acceptance Criteria: S/N Ratio value shall be 3 for LOD solution.

Limit of Quantification: The Quantification limit of an individual analytical procedure is the lowest amount of analyte in a sample which can be quantitatively determined with suitable precision and accuracy.

Preparation of $40 \mu \mathrm{g} / \mathrm{ml}$ solution: The Stock Solution has been prepared by weighing accurately weigh and transferred $10 \mathrm{mg}$ of Prasugral Working standard into $10 \mathrm{~mL}$ volumetric flasks. Added about $7 \mathrm{~mL}$ of Diluent and sonicated to dissolved it completely and make volume up to the mark with the same solvent. Further from the above Stock Solution pipette out $0.4 \mathrm{ml}$ into a $10 \mathrm{ml}$ volumetric flask and diluted up to the mark with diluent. Mixed well and then it was filter through $0.45 \mu \mathrm{m}$ filter.

Preparation of $5.4 \%$ solution At Specification level $(0.2 \mu \mathrm{g} / \mathrm{ml}$ solution): Pipette out $1 \mathrm{~mL}$ of solution into a $10 \mathrm{ml}$ of volumetric flask and dilute up to the mark with diluent. Pipette out $1 \mathrm{~mL}$ of solution into a $10 \mathrm{ml}$ of volumetric flask and dilute up to the mark with diluent. Further pipette out 5.4 $\mathrm{mL}$ of above diluted solution into a $10 \mathrm{ml}$ of volumetric flask and diluted up to the mark with diluent.

\section{Calculation of S/N Ratio:}

Average Baseline Noise obtained from Blank: $49 \mu \mathrm{V}$

Signal Obtained from LOD solution $(5.0 \%$ of target assay concentration): $499 \mu \mathrm{V}$

$\mathrm{S} / \mathrm{N}=499 / 49=10.1$

Acceptance Criteria: S/N Ratio value shall be 10 for LOQ solution.

Robustness: As part of the Robustness, deliberate change in the Flow rate, Mobile Phase composition, Temperature Variation was made to evaluate the impact on the method.

The flow rate was varied at 0.9 to1. $1 \mathrm{ml} / \mathrm{min}$. The Standard solution $40 \mu \mathrm{g} / \mathrm{ml}$ was prepared and analysed using the varied flow rates along with method flow rate. On evaluation of the above results, it can be concluded that the variation in flow rate do not affect the method significantly. Hence it indicates that the method is robust even by change in the flow rate $\pm 10 \%$. The data are represented in Table 5 .

The Organic composition in the Mobile phase was varied from $70 \%$ to $\mathbf{5 0 \%}$ : The Standard solution $40 \mu \mathrm{g} / \mathrm{ml}$ was prepared and analysed using the varied Mobile phase composition along with the actual mobile phase composition in the method. On evaluation of the above results, it can be concluded that the variation in $10 \%$ Organic composition in the mobile phase do not affect the method significantly. 
Hence it indicates that the method is robust even by change in the Mobile phase $\pm 10 \%$. The data are represented in Table 6 .

Table 1: The results are summarized for Precision

\begin{tabular}{|c|c|}
\hline Injection & Area \\
\hline Injection-1 & 616550 \\
\hline Injection-2 & 616002 \\
\hline Injection-3 & 614198 \\
\hline Injection-4 & 614670 \\
\hline Injection-5 & 614644 \\
\hline Average & 615213 \\
\hline Standard Deviation & 1007.7 \\
\hline \%RSD & 0.16 \\
\hline
\end{tabular}

Acceptance Criteria: The \% RSD for the area of five standard injections results should not be more than $2 \%$.
Table 2: The results for Ruggedness are summarized

\begin{tabular}{|c|c|}
\hline Injection & Area \\
\hline Injection-1 & 618936 \\
\hline Injection-2 & 618838 \\
\hline Injection-3 & 620387 \\
\hline Injection-4 & 620061 \\
\hline Injection-5 & 619434 \\
\hline Average & 619531 \\
\hline Standard Deviation & 681.4 \\
\hline \%RSD & 0.11 \\
\hline
\end{tabular}

Acceptance Criteria: The \% RSD for the area of five standard injections results should not be more than $2 \%$.

Table 3: The results for Accuracy are summarized

\begin{tabular}{|c|c|c|c|c|c|}
\hline $\begin{array}{c}\text { \% Concentration } \\
\text { (at specification Level) }\end{array}$ & Area & $\begin{array}{c}\text { Amount Added } \\
\text { (mg) }\end{array}$ & $\begin{array}{c}\text { Amount Found } \\
\text { (mg) }\end{array}$ & $\begin{array}{c}\text { \% } \\
\text { Recovery }\end{array}$ & $\begin{array}{c}\text { Mean } \\
\text { Recovery }\end{array}$ \\
\hline $50 \%$ & 612287 & 5.0 & 4.9 & $99 \%$ & $99.6 \%$ \\
\hline $100 \%$ & 1220663 & 10.0 & 9.9 & $99.4 \%$ & \\
\hline $150 \%$ & 1811336 & 15.0 & 14.9 & $101.8 \%$ & \\
\hline
\end{tabular}

Acceptance Criteria: The \% Recovery for each level should be between 98.0 to $102.0 \%$.

Table 4: The results are summarized for Linearity

\begin{tabular}{|c|c|c|c|}
\hline S.No & Linearity Level & Concentration & Area \\
\hline 1 & I & $20 \mu \mathrm{g} / \mathrm{ml}$ & 295857 \\
\hline 2 & II & $30 \mu \mathrm{g} / \mathrm{ml}$ & 463117 \\
\hline 3 & III & $40 \mu \mathrm{g} / \mathrm{ml}$ & 612270 \\
\hline 4 & IV & $50 \mu \mathrm{g} / \mathrm{ml}$ & 759987 \\
\hline 5 & V & $60 \mu \mathrm{g} / \mathrm{ml}$ & 924317 \\
\hline \multicolumn{2}{|c|}{ Correlation Coefficient } & 0.999 \\
\hline
\end{tabular}

Acceptance Criteria: Correlation coefficient should be not less than 0.999 .
Table 5: The results are summarized for Robustness with change in flow rate

\begin{tabular}{|c|c|c|}
\hline \multirow{2}{*}{$\begin{array}{c}\text { Flow Rate } \\
\text { (ml/min) }\end{array}$} & \multicolumn{2}{|c|}{ System Suitability Results } \\
\cline { 2 - 3 } & USP Plate Count & USP Tailing \\
\hline 0.9 & 2544 & 1.5 \\
\hline 1.0 & 2542 & 1.5 \\
\hline 1.1 & 2234 & 1.5 \\
\hline
\end{tabular}

Table 6: The results are summarized for Robustness with change in the composition of the Organic Phase

\begin{tabular}{|c|c|c|}
\hline \multirow{2}{*}{$\begin{array}{c}\text { Change in Organic Composition in the } \\
\text { Mobile Phase }\end{array}$} & \multicolumn{2}{|c|}{ System Suitability Results } \\
\cline { 2 - 3 } & USP Plate Count & USP Tailing \\
\hline $10 \%$ less & 2488 & 1.7 \\
\hline Actual & 2542 & 1.5 \\
\hline $10 \%$ more & 2276 & 1.5 \\
\hline \multicolumn{2}{|c}{} \\
\hline
\end{tabular}

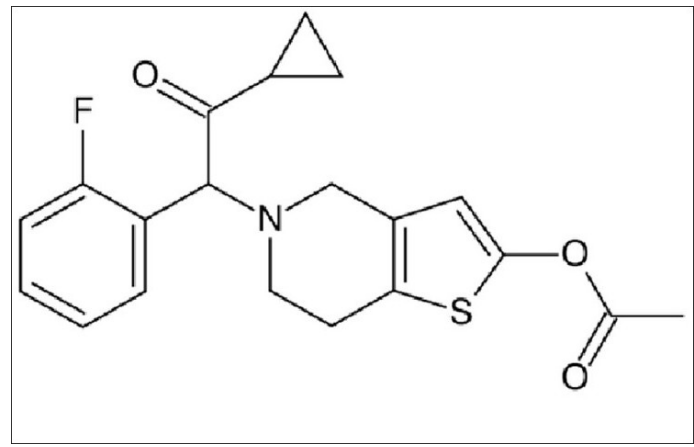

Figure 1: Chemical structure of Prasugrel 


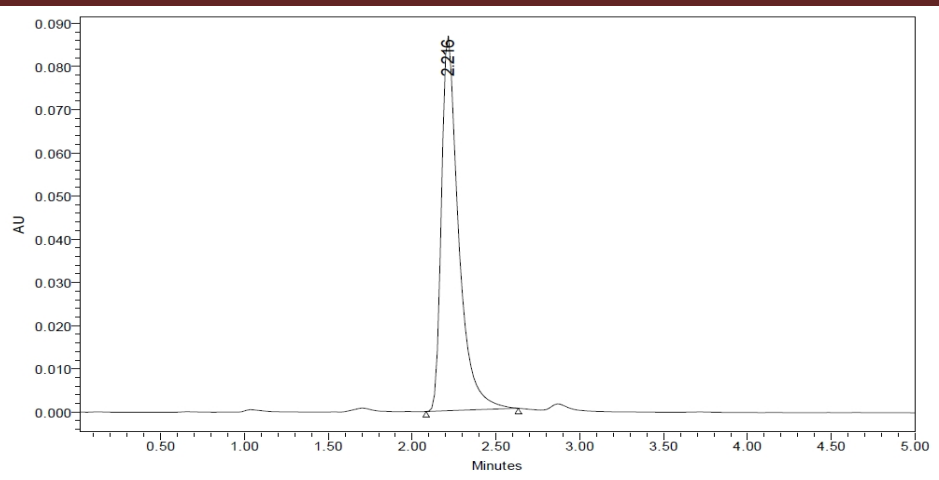

Figure 2: A model Chromatograph for Prasugrel

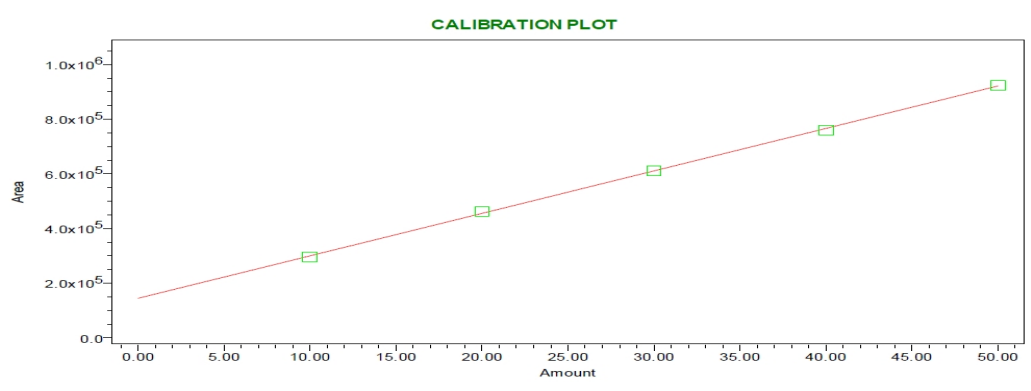

Figure 3: The Linearity Curve for Drug Prasugrel

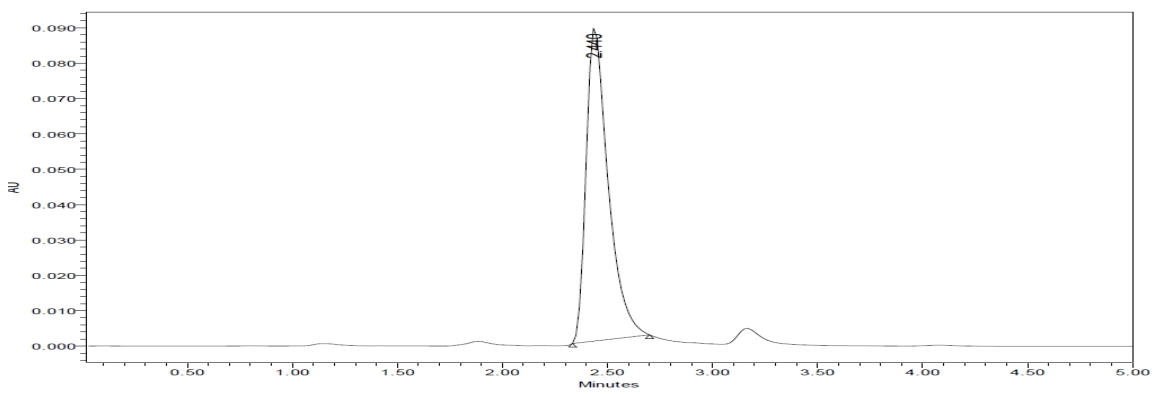

Figure 4: The Robustness chromatograph with decrease in the flow

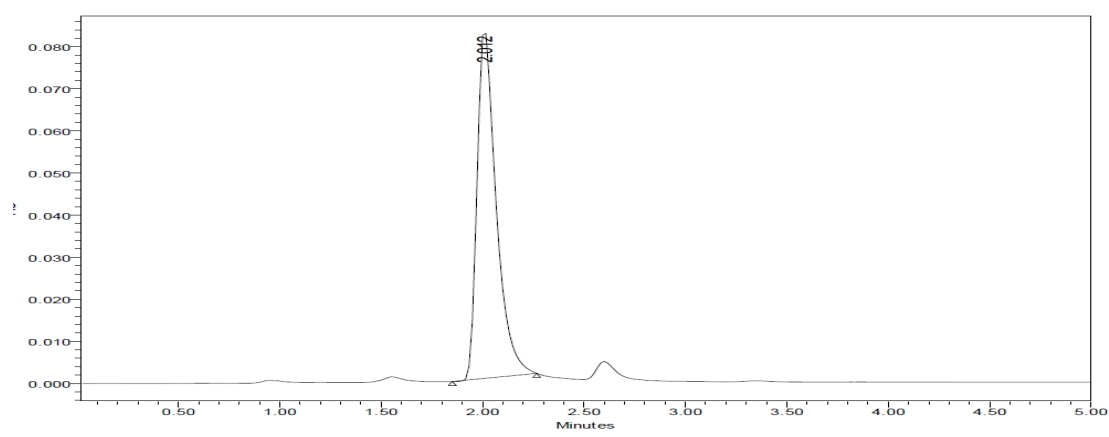

Figure 5: The Robustness Chromatograph with increase in the flow rate 


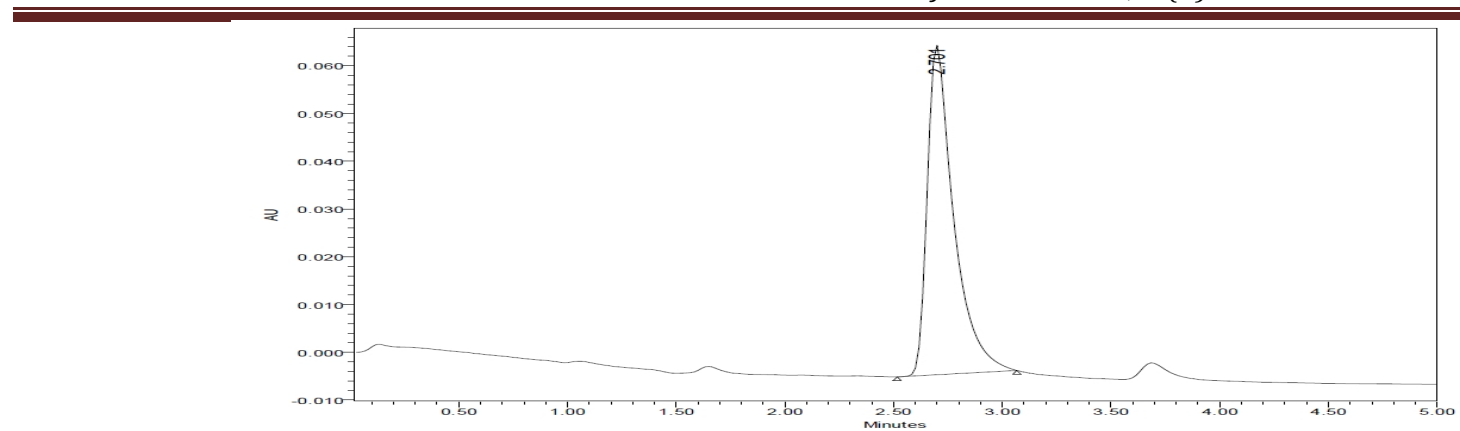

Figure 6: The Robustness chromatograph with less Mobile Phase composition

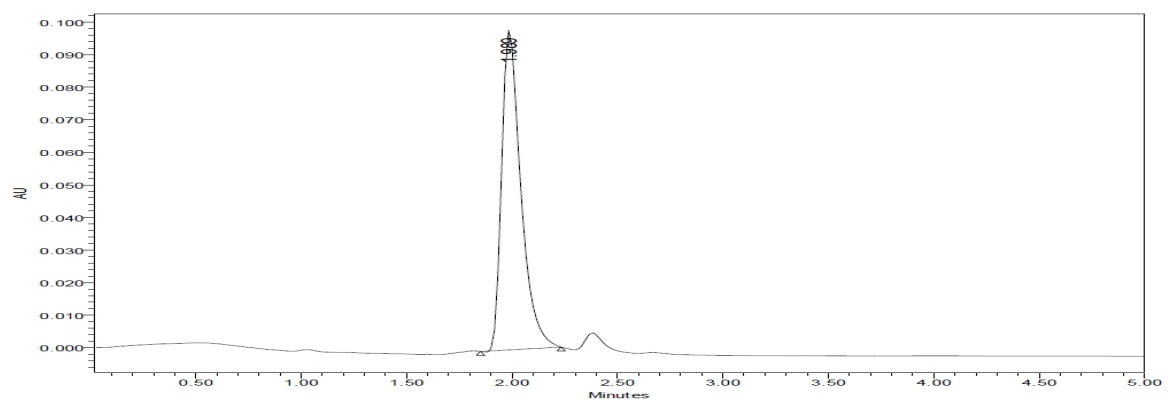

Figure 7: The Robustness chromatograph with more Mobile Phase Composition

\section{RESULT \& DISCUSSION}

The present study was carried out to develop a sensitive, precise and accurate HPLC method for the analysis of in pharmaceutical dosage forms. In order to method development under isocratic conditions, mixtures of Phosphate Buffer with $\mathrm{pH} 3$ adjusted with Orthophosphoric acid and Acetonitrile HPLC grade in different combinations were tested as mobile phase on a Symmetry C18 (4.6 x $150 \mathrm{~mm}, 5 \mu \mathrm{m}$, Make: XTerra) column. A binary mixture of Phosphate Buffer pH 3.0 and Acetonitrile in 30:70 v/v proportion was proved to be the most suitable of all combinations since the chromatographic peaks were better defined and resolved and almost free from tailing. The retention times obtained for Prasugral were around 2.216 min. A model chromatogram is shown as Figure 2. The Precision data has been represented by Table 1. When Prasugrel was analyzed by the proposed method in the intra and inter-day (Ruggedness) variation results, a low coefficient of variation was observed it has been represented in Table 2. This shows that the present HPLC method is highly precise and it has been represented by Figure 4 . The Accuracy data has been summarized in Table 3. In order to test the linearity of the method, five dilutions of the working standard solutions of the drug in the range of 20 to $60 \mu \mathrm{g}$ per $\mathrm{mL}$ for the drug were prepared. The data has been represented in Table 4. Each of the dilutions was injected into the column and the graph for the Linearity Curve has been represented in Figure 3. The method was duly validated by evaluation of the required parameters. Robustness of the method was found out by testing the effect of small deliberate changes in the chromatographic conditions in the chromatographic conditions and the corresponding peak areas. The factors selected for this purpose were flow rate and percentage composition variation in Phosphate buffer and Acetonitrile in the mobile phase. The method was found to be robust enough that the peak area was not apparently affected by small variation in the chromatographic conditions. The Fig.no.4, 5, $6 \& 7$ has been represented the Robust nature of the chromatograph. The system suitability parameters were within the limits as shown in Table 5 and 6 for the drug. Limit of detection and limit of quantification of the method were calculated basing on standard deviation of the response and the slope (s) of the calibration curve at approximate levels of the limit of detection and limit of quantification. The LOD for the drug was found to be $0.07 \mu \mathrm{g} / \mathrm{ml}$ and LOQ for the Drug was found to be $0.2 \mu \mathrm{g} / \mathrm{mL}$. The drug content formulations were quantified by using the proposed analytical method. The low coefficient of variation in the recovery data indicates the reproducibility of the method in dosage forms. It can be concluded that the proposed HPLC method is sufficiently sensitive and reproducible for the analysis of Prasugral in the Tablet formulation dosage forms within a short analysis time.

\section{CONCLUSION}

It can be concluded that the proposed RP-HPLC method developed for the quantitative determination of Prasugral in bulk and in its formulations is simple, selective, sensitive, accurate, precise and rapid. The method was proved to be superior to most of the reported methods. The mobile phases are simple to prepare and economical. The sample recoveries in the formulation were in good agreement with their respective label claims and they suggested non-interference of formulation excipients in the estimation. Hence this method can easily be adopted as an alternative method to reported ones for the routine determination of Prasugral depending upon the availability of chemicals and nature of other ingredients present in the sample. The method also finds use in clinical, biological and pharmacokinetic studies of Prasugral.

\section{REFERENCES}

1. Baker WL, White CM. Role of Prasugrel, a Novel P2Y12 Receptor Antagonist, in the Management of Acute Coronary Syndromes. American Journal of Cardiovascular Drugs Aug 1, 2009; 9 (4): 213-229. http://dx.doi.org/10.2165/1131209-00000000000000 PMid: 19655817 
2. Wiviott SD, Braunwald E, McCabe $\mathrm{CH}$ et al. (2007). "Prasugrel versus clopidogrel in patients with acute coronary syndromes". N Engl J Med 357 (20): 2001-15. http://dx.doi.org/10.1056/NEJMoa0706482 PMid: 17982182

3. ICH, Harmonized Tripartite Guideline. Validation of Analytical Procedure: Methodology (Q2B). International Conference on Harminizatio, 1997.

4. "FDA Drug Safety Communication: Reduced effectiveness of Plavix (clopidogrel) in patients who are poor Metabolizes of the drug". Drug Safety and Availability. Food and Drug Administration (United States). March 12, 2010. Retrieved March 15, 2013.

5. Silvano M, et al. (2011). "A case of resistance to clopidogrel and Prasugrel after percutaneous coronary angioplasty." J Thromb Thrombolysis 31(2): 233-4. http://dx.doi.org/10.1007/s11239-0100533-x PMid:21088983

6. O'Riordan, Michael. "Switching from clopidogrel to prasugrel further reduces platelet function". http://www.theheart.org. Retrieved 1 April 2011.

7. Bhatt DL (2007). "Intensifying Platelet Inhibition - Navigating between Scylla and Charybdis". N Engl J Med 357 (20): 2078-81. http://dx.doi.org/10.1056/NEJMe0706859 PMid:17982183

8. Duggan ST, Keating GM. Prasugrel: A Review of its Use in Patients with Acute Coronary Syndromes Undergoing Percutaneous Coronary Intervention. Drugs Aug 20, 2009; 69 (12): 1707-26. http://dx.doi.org/ $\underline{10.2165 / 10484190-000000000-00000}$ PMid: 19678718
9. Harshini B, Alekhya SVR, Manasa G, Vanitha Prakash K. Extractive Spectrophotometric Estimation of Prasugrel In Pharmaceutical Formulation. Res J Pharma, Bio and Che Sci 2011, 2 (3): 426-430.

10. Srikanth I, Sharmila P, Vijaya bharathi K, Raju M, Lakshma M, Nagarjuna K. A Validated Reverse Phase HPLC Method for the Estimation Of Prasugrel Hydrochloride In pharmaceutical Dosage Forms.J Inno trends Pharma Sci. 2011, 2 (5): 140-148.

11. Usha Rani G, Chandrasekhar B, Devanna N. Analytical Method Development and Validation of Prasugrel in Bulk and its Pharmaceutical Formulation using HPLC.J App Pharma Sci 2011, 01 (07): 172-175.

12. Borole TC, Mehendre R, Damle MC, Bothara KG. Development and Validation of Stability indicating HPTLC Method for Determination of Prasugrel. J Che, Pharma Res. 2010, 2(4): 907-913.

13. Kishore R, Venkateswara RA, Lavanya P, PaniKumar AD, Rama Krishna, Subba Reddy PV. Development of Validated RP-HPLC Method for the Estimation of Prasugrel $\mathrm{HCl}$ in Pure and Pharmaceutical Formulations.J Pharmacy Res 2011, 4(9): 3105-3110.

14. Pulla RP, Sastry BS, Prasad YR, Raju NA. Estimation of Prasugrel in Tablet Dosage Form by RPHPLC. Int J Chem Res 2011, 2(3): 34-36.

\section{Cite this article as:}

S. Ashutosh Kumar, J.V.L.N.Seshagiri Rao, K. Jhansi Rani, S. S. S. Jaya Madhuri, T. S. R. K. V. Prasad. Development and validation of RP-HPLC method for the estimation of Prasugrel in bulk as well in pharmaceutical dosages form. Int. Res. J. Pharm. 2013; 4(3):254-260 